\title{
Art as an educational tool in medicine
}

Human approach to reality is based on the construction of psychic representations that attempt to recreate such reality in order to interpret it and, thus, find a purpose for action. Although arbitrary, representations like signs (words) and symbols (images) have the relevance that tradition, consensus and practicality confer them. It is clear then that men do not operate directly with reality but with its representations, so there is always an unbridgeable gap between worldly stuff and words or images that attempt to represent it. ${ }^{1,2}$ This is what Immanuel Kant pointed out as the difference between the interpretation made by men (phenomenon) and what things actually are (noumenon). ${ }^{3}$

Of the two types of representations of reality that men are capable of generating: the sign and the symbol, the latter is the most ancient one from a phylogenetically perspective; and although the difference between both representations tends to vanish in certain situations, they usually differ in the following: ${ }^{4-8}$

- A symbol is made up of an image (visual, auditory, etc.) approachable through meaning, unlike a sign, which is based on a word that points to an abstract idea (concept).

- The relationship between a symbol and what it represents (symbolization) is unnecessary, i.e., many other images may be attributed to the same representation, while a single image may refer to various meanings (highly polysemous). On the contrary, the relationship between a sign and its meaning results necessary, i.e., it is almost exclusively pertinent (minimally polysemous); otherwise, words as such would disappear.

- The symbolic approach disregards words; it is based on meanings and is therefore more direct, but also more obscure (ambiguous). Precisely, this perceptive approach to the world through a symbolic representation is that initially experienced by human beings during their pre-verbal stage (infancy and early childhood); although language acquisition occurs approximately as of two years old. Language is a system of signs (words) that allows children to name worldly stuff and thus shape a linguistic segmentation of reality. Such new perspective of the world (signic) does not replace its predecessor (symbolic); instead, both become compounded and the latter continues displaying in that child's emotional life and artistic expression., ${ }^{4,7}$

- The signic approach to the world takes place in the cerebral cortex through language, and is characterized by a predominance of denotation (dictionary definition), interpretative accuracy, analytical exploration of deductions, dissection of what is observed in a set of terms and categories.

From this perspective, men have the illusion of being observers in a world that is external to them. Science is a paradigmatic example of this approach. On the contrary, the symbolic approach, whose typical example is art, consists in a sensory approach that takes place in the limbic lobe and is based on the intervention of visual symbols (painting, sculpture, architecture, filming), auditory symbols (music, poetry) and/ or kinetic symbols (acting, dancing), a language beyond the dictionary, with a predominance of connotation (informal meaning), interpretative heterogeneity and capable of exploring what cannot be deducted (indescribable), what can only be shown through a synthetic approach that brings together a set of emotions into a comprehensive perception.

Through art, men's perspective is more similar to the original, pre-verbal perspective, where the subject-object separation illusion was yet to be consolidated, contrary to the belief that there is an observer alienated from what is observed and in favor of a perception that does not fall into categories. ${ }^{7,9,10}$

Based on the above described concepts, it should be noted that, at present, medical education fundamentally gives priority to the biological aspects of medicine and leaves behind the aspects related to humanism, that is, both during the graduate and post-graduate courses there is a marked asymmetry between the scientific (signic) and the humanistic (symbolic) perspectives, always at the expense of the latter. As a result, many highly complex and key medical training subject matters, including an adequate tolerance of one's own and other people's uncertainty, how to develop a critical approach, the difference among information, knowledge and learning, knowledge of human nature, acquisition of communication skills, development of empathy, and the capability to 
recognize the difference between a disease (just a word) and a patient (a profound reality), are not correctly taught; moreover, most of the times the acquisition of such subjects are left to students' concern.

One way to change such reality would be to introduce art as an educational tool for professional training. Given the symbolic characteristic of art, this approach is ideal to convey the inffable aspects of humanity (fear of death, therapeutic power of empathy and love, etc.) and to operate as a trigger of inner certainties (Wittgenstein), knowledge of the world that we already have in an unconscious level (intuition) because we are a part of it, we just need them to surface to a consciousness level. ${ }^{2}$ The art of giving birth to ideas (Socrates), reuniting knowledge at a conscious level, could be further promoted through art's symbolic approach than through science's signic pathway, which can later strictly analyze intuitive perceptions so as to validate them.

Based on the concepts herein explained, we propose that both approaches to reality (art and science) should become integrated so as to improve the medical education process. This may be implemented by analyzing universal artistic masterpieces (literature, poetry, painting, etc.) that deal with key humanistic topics, and also by using those pieces, either appreciated (read, observed, etc.) or made (written, painted, etc.) by students as a source of inspiration (triggering factor) for the generation of ideas (hypothesis) that may clarify the unexplicable phenomena observed both at the healthcare and experimental levels.

In short, integrating art as a supplemental educational tool would be highly valuable for the improvement of medical training.

Carlos G. Musso, M.D., and Paula A. Enz, M.D. School of Medicine, Instituto Universitario del Hospital Italiano de Buenos Aires - Argentina

http:/ /dx.doi.org/10.5546/aap.2014.eng.494

\section{REFERENCES}

1. Musso CG, Enz PA. Semiótica médica. Principios lingüísticos y comunicacionales de uso médico. Buenos Aires: delhospital ediciones; 2007.

2. Wittgenstein L. Investigaciones filosóficas. Barcelona: Crítica; 2004.

3. Cassirer E. Kant: vida y doctrina. Buenos Aires: Fondo de Cultura Económica; 1948.

4. Moran JC. Proust más allá de Proust. La Plata: De la campana; 2001.

5. Sanz JC. Lenguaje del color. 2da ed. Madrid: H. Blume; 2009.

6. Goodman N. Los lenguajes del arte. Barcelona: Paidós; 2010.

7. Musso CG. La intersección de las paralelas: arte y ciencia en un único proceso cognitivo: hacia una nueva forma de investigar. Rev Hosp Ital B Aires 2012;32(1).

8. Heidegger M. Aclaraciones a la poesía de Hölderlin. Madrid: Alianza; 2009.

9. Musso CG, Enz PA. Arte y naturaleza humana VIII. Rev Hosp Ital B Aires 2012;32(2):86-7.

10. Job AJ. Comunicación y sentido. Fundamentos del respeto. Buenos Aires: De los cuatro vientos; 2011. 